\title{
Application of Electrical Resistivity Tomography for Soil Competence Study in University of Benin Teaching Hospital Environment, Edo State, Nigeria
}

\author{
Pessu B. ${ }^{1}$, Itiowe K. ${ }^{2 *} \&$ Ikponmwen M.O. ${ }^{1}$ \\ ${ }^{I}$ Department of Physics, University of Benin, Benin City, Nigeria. \\ ${ }^{2}$ Department of Earth Sciences, Arthur Jarvis University, Akpabuyo, Cross River State, Nigeria. Email: kiamukeitiowe@yahoo.com ${ }^{2 *}$
}

DOI: http://doi.org/10.38177/AJBSR.2021.3401

Copyright: ( $) 2021$ Pessu B. et al. This is an open access article distributed under the terms of the Creative Commons Attribution License, which permits unrestricted use, distribution, and reproduction in any medium, provided the original author and source are credited.

\section{ABSTRACT}

\begin{abstract}
This study was carried out to determine soil competence around University of Benin Teaching Hospital and its environs using electrical resistivity tomography method. The Wenner Schlumberger Array Profiling method was used to give information of the subsurface resistivity. The result of the study showed that in ERT 1, highly competent soil were observed with resistivity values between $725 \Omega \mathrm{m}$ and greater than $6546 \Omega \mathrm{m}$, which means that the area is underlain by clay sand at the top and sand/laterite/bedrock at the bottom. ERT 2 is characterized by highly competent soils with high resistivity values between $899 \Omega \mathrm{m}$ to greater than $7851 \Omega \mathrm{m}$, which indicates that the soil is underlain by sand/laterite/bedrocks. Furthermore, ERT 3 is group as highly competent soils, with resistivity values between $762 \Omega \mathrm{m}$ and greater than $6980 \Omega \mathrm{m}$; this shows that the profile 3 is underlain by sand/laterite/bed rock. The study shows that though most part of the area contains soils that are competent, because of the presence of clay which on most occasion in the Niger Delta are expandable, detailed Geophysical and Civil engineering studies should be carried out before the erection of high rising engineering structures such as network masts, buildings and water tanks within the study area.
\end{abstract}

Keywords: Competent, Resistivity, Tomography, Wenner, Soil.

\section{Introduction}

Electrical resistivity tomography has widely been used for many years to solve archaeological, geological, engineering and environmental problems. Over the last two decades, electrical resistivity surveying method has undergone some dramatic changes. In Nigeria, which is often referred to as the one of the most populated black nation in the world, the country has experienced building collapse in several structures under construction and shortly after construction. It is worthy of note that most of these collapse results from the lack of appropriate geophysical investigations to determine the subsurface competence. Thus most of these buildings were built on soils that lack the capacity to bear the weight of the structures.

It is important in assessing the geology of any place to suit the type of structures and buildings to be erected. Near-surface soil may consist of expansive clay that expands or shrinks as a result of change in moisture content [1]. Subsurface geological features such as voids, fractures, water table close to the surface and bedrock with small depth are among the common limitations to building erection and their foundations [2].

The competence of any geological material is one the most significant concept in civil engineering practice that is usually taken into consideration in construction work. Furthermore, the thickness of the topsoil plays an eminent function in foundation design. Competence of any earth material is controlled by various factors and some of which includes mineral constituents, characteristics of the grain contacts and weathering agents.

Since civil engineering structures are erected on geological earth materials, it is paramount to undertake a pre-construction investigation of the subsoil to discover the strength of the subsoil [3]. Geophysical investigations are generally considered to be the principal methods of finding underground cavities particularly in urban areas. 
These cavities present a major risk when heavy duty machinery is employed in a new construction area. The voids can be air filled, completely filled or partially filled with water which could cause electrical resistivity contrast with respect to the surrounding rock type or soil [3]. Therefore the usefulness of geophysical techniques which provide information on the heterogeneous of soil particles and other physical parameters that control the subsoil competency cannot be misconstrue when comparing its cost effectiveness, speed, and robust ability to give an accurate arrangement of the rock types in the subsurface formation [4]-[6].

The recurrent collapse of several engineering structures like roads, dams, pavements and buildings have been attributed to various factors. These factors include presence of bad design, low strength materials, use of low quality materials and poor supervision [7]-[9]. Failure of these structures will pose a threat to live and properties, extra cost in the repairing, rehabilitating and reconstruction of these failed structures.

Many researchers have employed electrical resistivity method in different geologic environments. 2D electrical resistivity tomography and geotechnical methods were employed for site characterization in the School of Management area, Lagos State Polytechnic, Lagos. Based on their findings, the main rock types consist of sand and sandy clay materials [10]. They reported that the northern parts of the area consists of mechanically unstable soil formations which is capable of been pernicious to building structures and the southern parts consist of competent geo-material for the foundation of any engineering structures. 2D electrical resistivity tomography was used to investigate foundation defect at Ogudu Estate in Lagos State, Nigeria [11]. The outcome of their results provided valuable information on the horizontal and vertical variation of the area which provided the necessary information for erecting engineering structures. Deep foundations were suggested for buildings in this area.

2D electrical resistivity tomography was employed to ravel the cause of recurrent failure of the faculty building in Olabisi Onabanjo University [12]. The result showed a faulted zone with vertical and sub-vertical linear features with resistivity values as low as $5 \Omega \mathrm{m}$. $2 \mathrm{D}$ electrical tomography and geotechnical methods was carried out to assess the competence of near surface formation at the collapsed lecture hall in Adekunle Ajasin University, south-eastern, Nigeria [13]. The findings revealed that the lecture hall was built on a poor foundation material. Electrical resistivity tomography was used to determine soil competence and corrosivity in Ladoke Akintola University of Technology Ogbomoso, Nigeria [14]. The topsoil quality varied between highly competent (750 ohm-m) and moderately competent (107-347 ohm-m).

\section{Location and geology of the study area}

The study area is located in University of Benin, Ovia North-East Local government Area of Benin City, Edo State. Itis located within latitudes $6^{\mathrm{O}} 19^{\prime} 55^{\prime} \mathrm{N}$ and $6^{\mathrm{O}} 19^{\prime} 93^{\prime} \mathrm{N}$ and longitudes $5^{\mathrm{O}} 36^{\prime} 10^{\prime} \mathrm{E}$ and $5^{\mathrm{O}} 36^{\prime} 16^{\prime \prime} \mathrm{E}$ (Fig.1). Geologically, the study area is located in the Niger Delta sedimentary basin. As stated by [16], South America and Africa continent dissociation began as a result of the build-up of the aulacogen which initiated the development of the delta. The delta has three Formations which are deposited in environments varying from marine, deltaic and fluvial environments [17],[18], these formations are: the marine Akata Formation, this Formation is situated at the base of the delta and consists of dark gray shales and silts. The age of the Formation ranges from Late Maastrichtian to Late Eocene epoch [19]. The Agbada Formation lies above the Akata Formation and it consists of intercalation 
of sandstones and shales [20]. The age of the Agbada Formation using foraminefera biostratigraphy ranges from Oligocene to Early Miocene [21].

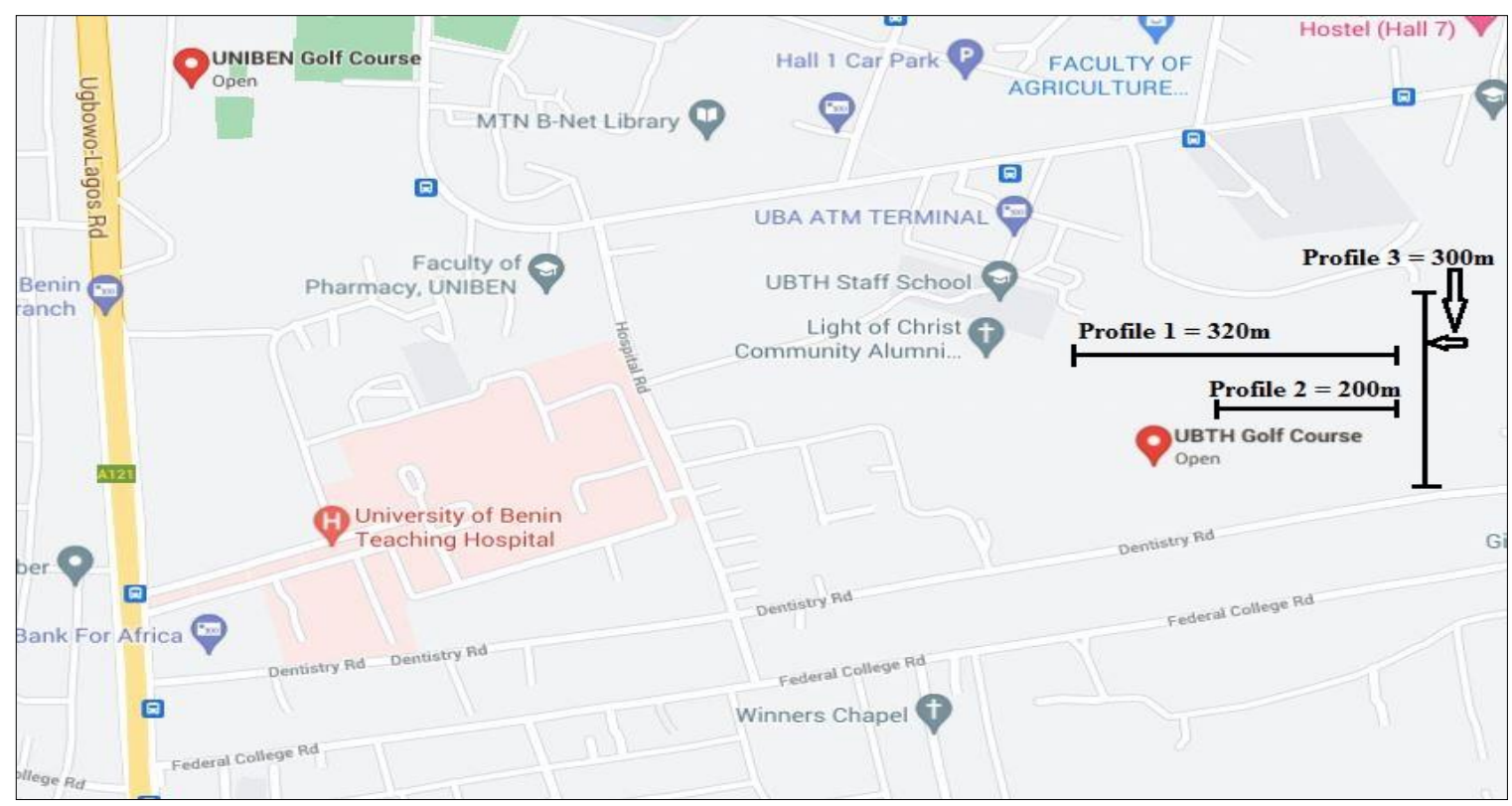

Fig.1. Map showing University of Benin Teaching Hospital and Environs [15]

The Benin Formation lies above the Agbada Formation. The Formation consists of sand to boulder fraction, with sub-angular to well-rounded grains which are moderately to well sorted. It is a water bearing Formation that serves as a source of portable water in the Niger Delta Basin [22].

\section{Materials and Method}

\subsection{Materials}

Pasi earth resistivity meter was the main equipment used to carry out the two-dimensional resistivity survey of the area. Other accessories engaged are: twenty one (21) electrodes, global positioning system (GPS), measuring tapes, hammer and umbrella.

\subsection{Method}

Three (3) electrical resistivity tomography (ETR) measurements were carried out within the University of Benin Teaching Hospital (UBTH) Golf Course (Club) in Benin City. In this method thirty (30) electrodes were positioned alone a straight line with the potential electrodes on the inside and the current electrodes on the outside. The electric current and electrode potential arrangements were line up using constant electrode spacing (Wenner array profiling method). The minimum electrode spacing used was $10 \mathrm{~m}$ (for data level $\mathrm{n}=1$ ), while the maximum electrode spacing used was 140m (for data level $n=14$ ). Two parallel and one transverse profile was carried out in the survey area. The method for executing the electrical resistivity tomography is reported in [23].

\section{Results and Discussion}

The analysis of the data was achieved by using RES2DINV 3.54.44 as instructed by [24]. The inverted resistivity tomograms are shown in Figures 3- 5. 


\subsection{Evaluation of soil competence}

Idornigie and Olorunfemi (2006) model was used to group the competence of the soil into different competence zones (Table 1).

Table 1. Apparent resistivity competence model [25]

\begin{tabular}{|l|l|l|}
\hline Apparent resistivity & Lithology & Competence rating \\
\hline$<100$ & Clay & Incompetent \\
\hline $100-350$ & Sand clay & Moderately competent \\
\hline $350-750$ & Clayey sand & Competent \\
\hline$>750$ & Sand/laterite/bedrock & Highly competent \\
\hline
\end{tabular}

\subsection{Evaluation of soil competence for electricity resistivity tomography 1}

Figure 2 shows two resistivity zones that are delineated from the subsurface profile, surveyed at different surface points. A resistivity zone (dark blue colour) with resistivity less than $993 \Omega \mathrm{m}$; it is isolated at surface points of $88 \mathrm{~m}$ to $110 \mathrm{~m}$ and $220 \mathrm{~m}$ to $280 \mathrm{~m}$. It has depth of $2.56 \mathrm{~m}$ to $10 \mathrm{~m}$ and $2.56 \mathrm{~m}$ to $13.0 \mathrm{~m}$. The second resistivity zone (light blue, green, yellow, brown, orange, ox blood red and purple colours) is a higher resistivity zone greater than 993 $\Omega \mathrm{m}$. It is isolated at surface point of $15 \mathrm{~m}$ to $95 \mathrm{~m}, 110 \mathrm{~m}$ to $205 \mathrm{~m}$ and $275 \mathrm{~m}$ to $350 \mathrm{~m}$. The depth varies at equal length throughout the tomography from $2.56 \mathrm{~m}$ to $53.6 \mathrm{~m}$. In ERT 1, competent soil was observed with resistivity values less than $997 \Omega \mathrm{m}$, which shows that the sediment is underlain by clay sand. Other areas within the profile are characterized by highly competent soil with resistivity value greater than $997 \Omega \mathrm{m}$, which indicate that the soil is underlain by sand/laterite/bedrocks.

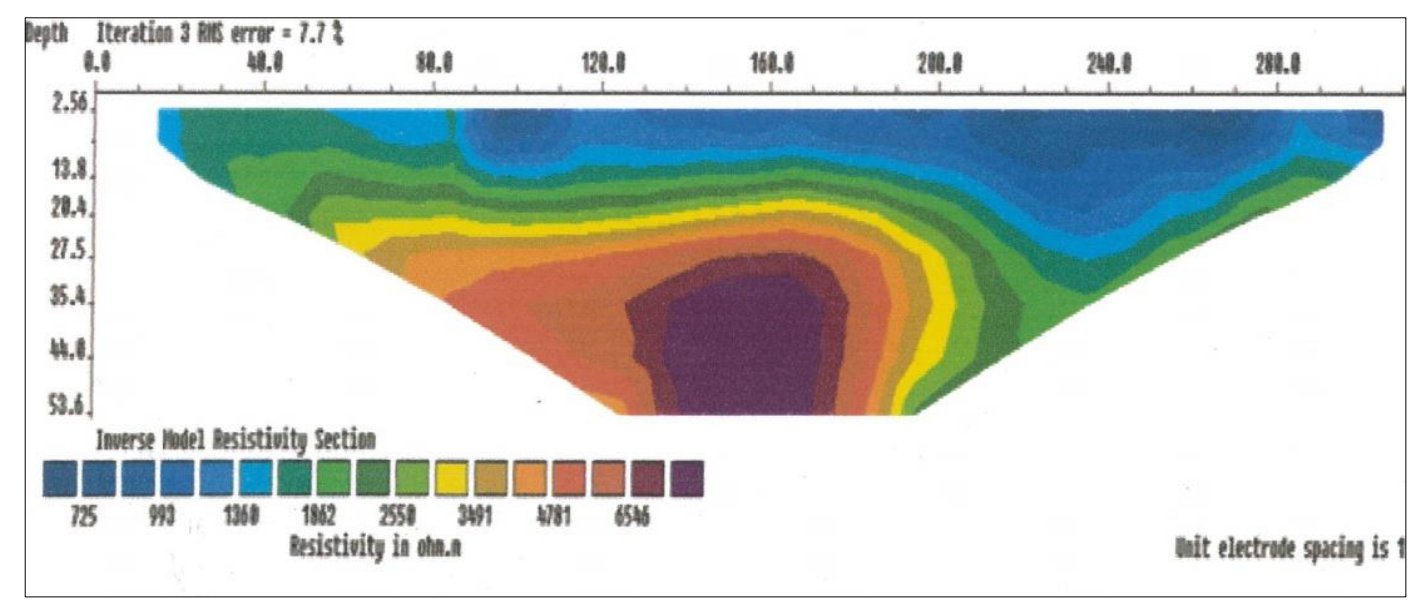

Fig.2. 2D inverse resistivity model for profile 1 taken at the gulf course

\subsection{Evaluation of soil competence for electricity resistivity tomography 2}

This area has a high resistivity zone. It has resistivity greater than $899 \Omega \mathrm{m}$ (dark blue, light blue, dark green, light green, yellow, brown, orange, horse blood and purple colours) and it is isolated at surface points of $15 \mathrm{~m}$ to $185 \mathrm{~m}$, and depth of $2.56 \mathrm{~m}$ to $27.5 \mathrm{~m}$ (Figure 3). 
In ERT 2, highly competent soils were observed all through the profile with resistivity values greater than $899 \Omega \mathrm{m}$. This indicates that the entire area is underlain by sand/laterite/bedrock.

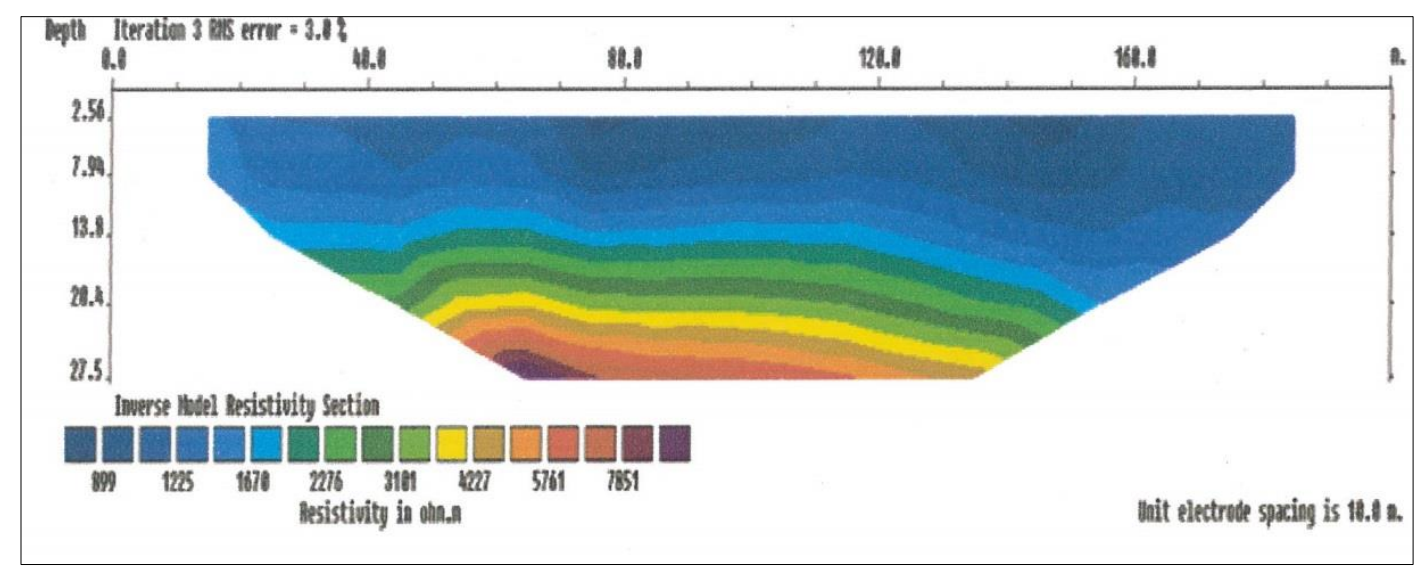

Fig.3. 2D inverse resistivity model for profile 2 taken at the gulf course

\subsection{Evaluation of soil competence for electricity resistivity tomography 3}

This area has a high resistivity zone depicted by dark blue, light blue, dark green, light green, yellow, brown, orange, horse blood and purple colours), with resistivity greater than $750 \Omega \mathrm{m}$. This zone has isolated surface points between $15 \mathrm{~m}$ to $305 \mathrm{~m}$. It has depth that covers the entire tomography (between $2.60 \mathrm{~m}$ to $54.3 \mathrm{~m}$ ) (Figure 4 ).

Also for ERT 3, highly competent soils were obtained for ERT 3 with resistivity value greater than $750 \Omega \mathrm{m}$. This shows that the entire region is underlain by sand/laterite/bed rock.

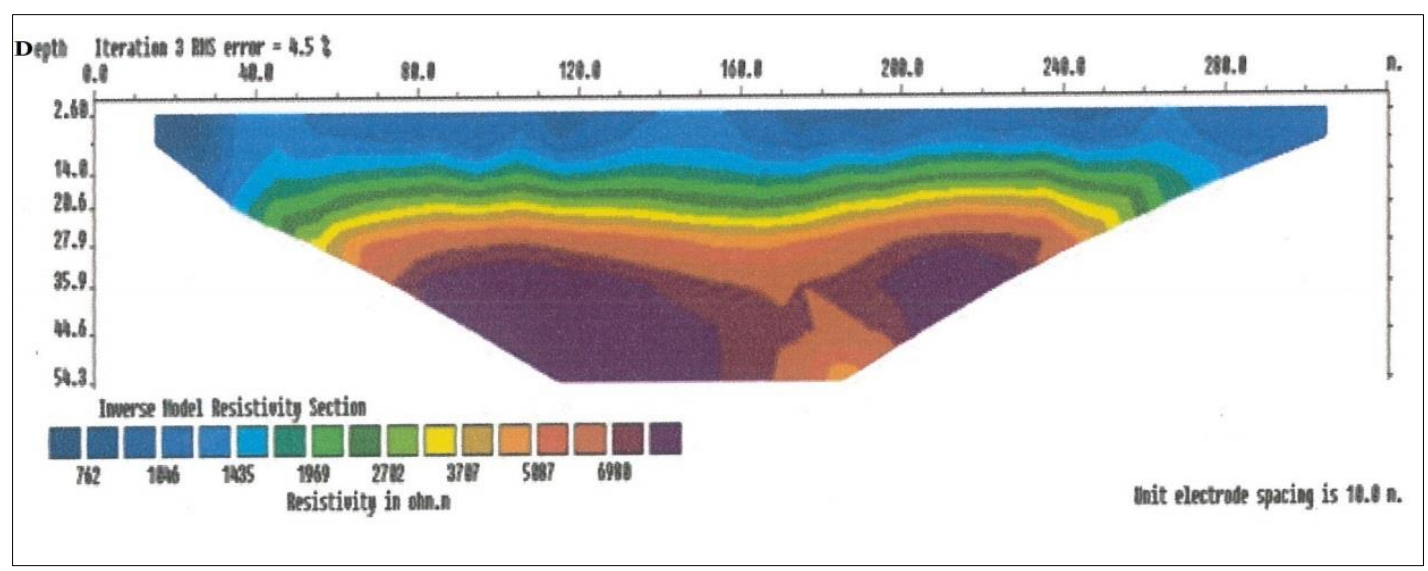

Fig.4. 2D inverse resistivity model for profile 3 taken at the gulf course

\section{Conclusion}

The application of two dimensional electrical resistivity tomography for soil competence has been successfully carried out in University of Benin Teaching Hospital and environs. From the study it was discovered that the area is dominated with competent and highly competent soils. However the study also shows that in some part of the area of interest (e.g. Profile 1), there was the presence of a substantial underlay of clay, which on most occasion in the Niger delta, usually expands when it absorbs water over a considerable period of time and in most occasion leads to cracks, with origin that can be traced to the foundation in most buildings and other civil engineering structures within the Niger Delta. Therefore it is recommended that before the erection of any sustainable building within the 
study area, detailed geophysical and civil engineering studies should be carried out so as to proffer sustainable foundation construction measures to take. This may involve excavation of all top soil down to bedrock, or/and setting up reinforced foundation before the erection of any high rising structure such as network masts, buildings and water tanks within the study area. It is believed that if such measures are put in place most of the structures will be completely devoid of any near future cracks and possible collapse and will therefore stand the test of times.

\section{Declarations}

\section{Source of Funding}

This research did not receive any grant from funding agencies in the public, commercial, or not-for-profit sectors.

\section{Competing Interests Statement}

The authors declare no competing financial, professional and personal interests.

\section{Consent for publication}

Authors declare that they consented for the publication of this research work.

\section{Availability of data and material}

Authors are willing to share relevant data and material according to the relevant needs.

\section{References}

[1] Sands, TB., (2002). Building stability and tree growth in swelling London clay -implication for pile foundation design (www.agu.org).

[2] Ugwu, G.Z., \& Ezema P.O., (2013). 2D Electrical Resistivity Imaging for the Investigation of the Subsurface Structures at the Proposed Site for Kauridan Estate at Ibagwa - Nike, Southeastern Nigeria. International Journal of Scientific Research in Knowledge, 1(12): 528-535.

[3] Abong, A.A., Egor, A. O., \& Ekwok A., (2013). 2D electrical resistivity tomography survey of soil competence in Cross River University of Technology Calabar campus- South South Nigeria. Journal of Science, Engineering and Technology, 6 (2): 139-148.

[4] Olorunfemi, M.O., Ojo, J.S., \& Ojelabi, E.A., (2002). Geophysical Site Investigation of the premises of Idu Flow Station Nigerian Agip Company (NAOC) Limited, (For multipurpose Oil Services Company Limited, Port Harcourt), Technical Report.

[5] Akintorinwa, O.J., \& Adesoji, J.I., (2009). Application of Geophysical and Geotechnical Investigations in Engineering Site Evaluation. International Journal of Physical Sciences, 4(8): 443-454.

[6] Akintorinwa, O.J., \& Adeusi, F.A., (2009). Integration of Geophysical and Geotechnical Investigations for a Proposed Lecture Room Complex at the Federal University of Technology, Akure, SW, Nigeria. Journal of Applied Sciences, 2(3): 241-254. 
[7] Oyedele, K.F., Oladele, S., \& Adedoyin, O., (2011). Application of Geophysical and Geotechnical Methods to Site Characterization for Construction Purposes at Ikoyi, Lagos, Nigeria. J. Earth Sci. Geotech. Eng., 1(1): 87-100. [8] Salami, B.M, Falebita, D.E, Fatoba, J.O., \& Ajala, M.O., (2012). Integrated Geophysical and Geotechnical Investigation of A Bridge Site- A Case Study of A Swamp/Creek Environment in Southeast Lagos, Nigeria. Ife J. Sci, 14(1): 75-82.

[9] Ayolabi, E.A., Enoh, I.E., \& Folorunsho, A.F., (2013). Engineering Site Characterization Using 2-D and 3-D Electrical Resistivity Tomography. Earth Science Research, 2(1): 133-142.

[10] Coker, J.O., (2015). Integration of Geophysical and Geotechnical Methods to Site Characterization for Construction Work at the School of Management Area, Lagos State Polytechnic, Ikorodu, Lagos, Nigeria. International Journal of Energy Science and Engineering, 1(2): 40-48.

[11] Ayolabi, E.A., Folorunhso, A. F., \& Jegede, O. E., (2012). Application of 2D electrical resistivity Tomography in Geotenical investigation of foundation defects: A case study of Ogudu Estate in Lagos, Nigeria. Journal of Geology and Mining Research, 3(12): 142-151.

[12] Folorunso, A.F., Ayolabi, E.A., Ariyo, S.O., \& Oyebanj, I.O., (2012). Fault Presence under a Failing Building Complex Mapped By Electrical Resistivity Tomography. Mineral Wealth 166/2012, 47- 55.

[13] Okpoli, C.C., (2014). 2D Resistivity image and geotechnical investigation of structural collapsed lecture theater in Adekunnle University, Akunngba-Akoko, Southwestern Nigeria. Env. Res., Eng. \& Manag., 3: 4 9-59.

[14] Bayowa, O.G., \& Olayiwola, N.S., (2015). Electrical Resistivity Investigation for Topsoil Thickness, Competence and Corrosivity Evaluation: A case study from Ladoke Akintola University of Technology, Ogbomoso Nigeria. $2^{\text {nd }}$ International Conference on Geological and Civil Engineering IPCBEE, 80: 52-56.

[15] Mapcarta, (2021). University of Benin Teaching Hospital Golf Course, Mapcarta.com/33098842.

[16] Short, K.C., \& Stauble, A.J., (1967). Outline Geology of Nigeria Delta. American Association of Petroleum Geologist, 51: 761-779.

[17] Weber, K. J., \& Daukoru, E.M., (1975). Petroleum geology of the Niger Delta. In Proceedings of the 9th World Petroleum Congress, Geology. Applied Science Publishers, Ltd. London, 2: 210-221.

[18] Weber, (1987). Hydrocarbon distribution patterns in Nigeria growth faults structures controlled by structural style and stratigraphy. Journal of Petroleum Science and Engineering, 91-104.

[19] Itiowe K., Lucas F.A., \& Olise C.O., (2020). Foraminiferal Biostratigraphy and Paleoenvironmental analysis of the sediments penetrated by Sahaiawei-1 Well in the Northern Delta Depobelt, Niger Delta Basin. Global Journal of Geological Series, 18: 119-126.

[20] Itiowe K., \& Lucas F.A., (2020a). Palynological Zonation and Paleoclimatic Condition of the Sediments Penetrated by Ash-3 Well in the Greater Ughelli Depobelt, Niger Delta Basin. An International Journal of Pure and Applied Sciences, 19(1): 37-48. 
[21] Itiowe K., \& Lucas F.A., (2020b). Foraminiferal Biostratigraphy and Paleoenvironmental Study of the Sediments Penetrated within the interval of 6030ft. to 11115ft. of Ash-3 Well in the Greater Ughelli Depobelt, Niger Delta Basin. An International Journal of Pure and Applied Sciences, 19(1): 130-150.

[22] Esu, E.O., \& Amah, E.A., (1999). Physico-chemical and bacteriological quality of natural water in parts of Akwa Ibom and Cross River States Southern Nigeria. Global Journal of Pure and Applied Sciences, 5(4): 525-534. [23] Loke, M.H., (2002). Electrical Imaging Surveys for Environmental and Engineering Studies. (A Practical Guide to 2-D and 3-D Surveys).

[24] Loke, M.H., \& Barker, R.D., (1996). Rapid Least - Squares Inversion of Apparent. Resistivity Pseudosections by a Quasi-Newton Method. Geophysical Prospecting, 44: 131-152.

[25] Idornigie, A.I., \& Olorunfemi, M.O., (2006). Electrical Resistivity Determination of Subsurface Layers, Subsoil Competence and Soil Corrosivity at an Engineering Site Location in Akungba -Akoko, Southwestern Nigeria. Ife Journal of Science, 8: 22-32. 